O.Gaponyuk, Doctor of Technical Sciences, Professor, E.mail: oleg_odessa@me.com RESEARCHERID.com/rid/U-7792-2017，ＯRCID.org/0000-0002-9577-4417 A.Aleksashin, Ph.D., Associate professor, E.mail: aleksashin48@gmail.com RESEARCHERID.com/rid/U-7832-2017, ORCID.org/0000-0001-6423-4605 G.Goncharuk, Ph.D., Associate professor, E.mail: ganna.goncharuk22@ gmail.com RESEARCHERID.com/rid/U-7642-2017, ORCID.org/0000-0002-8361-0810 Odessa National Academy of Food Technologies 112, Odessa, Kanatna Str., Ukraine, 65039

\title{
MANAGEMENT OF TRANSPORTATION AND TECHNOLOGICAL EQUIPMENT OF THE INDUSTRY BASED ON THE SMART SYSTEM
}

\begin{abstract}
High productivity and power of technological and transport mechanisms, large capacity and number of storage equipment, a variety of types of grain crops simultaneously processed at the elevator require the operator to make a lightning-fast decision, the optimal choice of grain transportation routes.

One of the first control systems consisted of huge energy-intensive cabinets with starting equipment, allowing remote control of equipment, without the functions of elementary control of their operation.

As storage volumes increased, these systems were supplemented with relay cabinets, whose task was to conduct interlocked control of an ever-increasing number of mechanisms, so that at least somehow it was possible to control such a complex. These relay cabinets had a low degree of reliability (contact elements), consumed a large amount of energy, and required the constant presence of large maintenance personnel.

The era of microelectronics has come, which completely changed the idea of the capabilities of control systems. At first, it seemed very expensive and not a quick payback. But every year, the cost of automation equipment is decreasing, reliability has grown to high levels and this technique has come to the management systems of grain storages and elevators.

Modern automation at the majority of Ukrainian elevators makes it possible to control technological processes. At the same time, many processes are regulated in a mode that requires a sufficiently high qualification of service personnel. The exchange of data on the operation of SMART-INDIVIDUAL equipment is carried out by logical controllers by polling sensors, generating control actions, monitoring equipment operating modes with display in the WEB-interface system. The SMART-INDIVIDUAL system has undeniable advantages over existing centralized control and management systems. SMART technology is inextricably linked with the dispatch control and data collection system - SCADA, designed to monitor and supervise a large number of remote objects or one geographically distributed object. The SMART-INDIVIDUAL system is equipped with a module with a regulation for monitoring parameters, equipment according to the passport characteristics. At the same time, the system maintains an archive and controls the timing of maintenance. The laboratory installation SMART-INDIVIDUAL includes technological and transport equipment, which is most used in the elevator industry: air filter ZEO-FCS, bucket elevator ZEO-BE, scraper chain conveyor ZEO-DC. On the basis of the SMART-INDIVIDUAL software and hardware complex at the Department of Technological Equipment for Grain Production of the Odessa National Academy of Food Technologies, students are trained in the new specialty "IT service of equipment".
\end{abstract}

Key words: SMART-INDIVIDUAL, SMART technology, SCADA, control, management, information, intelligent systems.

\section{Introduction}

If you plunge into the history of mankind, the problem of preserving the harvested crop has always been relevant. Farmers were constantly forced to come up with various ways to protect grain from damage as a result of improper transportation, improper storage, violation of grain storage regimes, etc.

Time makes its own adjustments. After all, today we are not talking about a peasant who needs to save several tons of grain collected by him in order to feed his family. We are talking about large and small farms, agricultural firms, corporations, grain traders whose grain turnover amounts to thousands, hundreds of thousands of tons of grain.

It is not a secret for anyone that even in recent times, the main crop losses took place precisely at the storage stage as a result of scratches and impacts, grain losses during its repeated transportation, drying, etc.

In order for the manufactured products to remain competitive in the market, the owners are faced with the issue of equipping them with an automatic control system.
The reason for this is that today it is impossible to imagine effective manual control of a modern, high-performance complex.

High productivity and power of technological and transport mechanisms, large capacity and number of storage equipment, a variety of types of grain crops simultaneously processed at the elevator require the operator to make a lightning-fast decision, the optimal choice of grain transportation routes.

One of the first control systems consisted of huge energy-intensive cabinets with starting equipment, allowing remote control of equipment, without the functions of elementary control of their operation.

As storage volumes increased, these systems were supplemented with relay cabinets, whose task was to conduct interlocked control of an ever-increasing number of mechanisms, so that at least somehow it was possible to control such a complex. These relay cabinets had a low degree of reliability (contact elements), consumed a large amount of energy, and required the constant presence of large maintenance personnel. 
The era of microelectronics has come, which completely changed the idea of the capabilities of control systems. At first, it seemed very expensive and not a quick payback. But every year, the cost of automation equipment is decreasing, reliability has grown to high levels and this technique has come to the management systems of grain storages and elevators.

In the modern sense, the automation of elevator or grain storage facilities implies a system of a whole range of tasks that includes:

- full control and monitoring of grain pumping routes inside the elevator; er transport;

- acceptance and shipment of road, rail, sea or riv-

- control of conveyors, gate valves, rocker valves and distributors;

- management of associated aspiration systems;

- prompt collection and processing of data on the condition of all equipment;

- diagnostics of accidents and deviations of parameters from the technological process with the issuance of an alarm and information about the nature of the malfunction; ping routes;

- actions to prevent blocking of equipment, stop-

- control of motor load currents, regulation of the degree of rash in order to avoid the onset of emergency situations and at the same time ensuring the maximum performance of transport equipment;

- control of product availability in bunkers and silos;

- prevention of mixing of crops;

- display of technological parameters in various graphical forms;

- keeping records of production work.

Modern automation at the majority of Ukrainian elevators makes it possible to control technological processes in the amount of $30-40 \%$. At the same time, many processes are regulated in a mode that requires a sufficiently high qualification of service personnel.

\section{Results and discussion}

On the basis of the "Research and Production Complex" Plant of Elevator Equipment "ZEO - ONAFT", which includes teachers and employees of the Department of Technological Equipment for Grain Production of the Odessa National Academy of Food Technologies and specialists of the Plant of Elevator Equipment, an educational and scientific laboratory was created on the basis of software -Hardware complex for automated control of technological and transport equipment of elevators, called "SMART-INIVIDUAL".

Self-Monitoring and Reporting Technology SMART is an effective technology for setting and formulating goals, which stands for "smart goal" and combines the capital letters of the English words for what the real goal should be: Specific - Measurable - Attainable - Relevant ( relevance) - Time-bounded (definiteness in time). In this case, the goal should be as clear and specific as possible; when setting goals, the final result should be clearly presented. At the same time, the goals should be measurable, so that you can know that they have been achieved, while it is useful to highlight not only the final, but also intermediate criteria, assessments. The goals must be achievable in terms of external factors and internal resources and are relevant, i.e., they must correlate with other, more general, as well as with strategic goals, and work towards their achievement, taking into account that the goal must be clearly defined in time, there must be a specific time frame (and intermediate milestones) for its achievement [1].

SMART technology is inextricably linked with the supervisory control and data acquisition system SCADA (Supervisory Control and Data Acquisition Systems). SCADA systems are designed for monitoring and supervisory control of a large number of remote objects or one geographically distributed object. The main task of SCADA systems is to collect information about a variety of remote objects from control points and display this information in a single dispatch center. The SCADA system must also provide long-term archiving of the received data. The dispatcher often has the ability not only to passively observe the object, but also to control it, responding to various situations.

The tasks of SCADA systems include:

- data exchange with USO (communication devices with the object, that is, with industrial controllers and input / output boards) in real time via drivers;

- information processing in real time;

- displaying information on the monitor screen in a human-readable form;

- maintaining a real-time database with technological information;

- emergency signaling and management of alarm messages;

- preparation and generation of reports on the progress of the technological process;

- providing communication with external applications (database management systems, spreadsheets, text messages, etc.)

Let's note the features of the control process in SCADA systems:

- in SCADA systems, the presence of a person (operator, dispatcher) is required;

- any wrong action can lead to the failure of the control object or even catastrophic consequences;

- the dispatcher has, as a rule, overall responsibility for the management of the system, which, under normal conditions, only occasionally requires adjustment of parameters to achieve optimal functioning;

- most of the time the dispatcher is passively watching the displayed information. The active participation of the dispatcher in the control process occurs infrequently, usually in the event of critical events - failures, emergency and abnormal situations, etc.

- the operator's actions in critical situations can be strictly limited in time (several minutes or even seconds) [2]

The exchange of data on the operation of SMART-INDIVIDUAL equipment is carried out by logical controllers by polling sensors, generating control actions, monitoring equipment operation modes with display in the WEB-interface system.

The main functions of SMART-INDIVIDUAL are:

- intellectualization of the work of technological, 


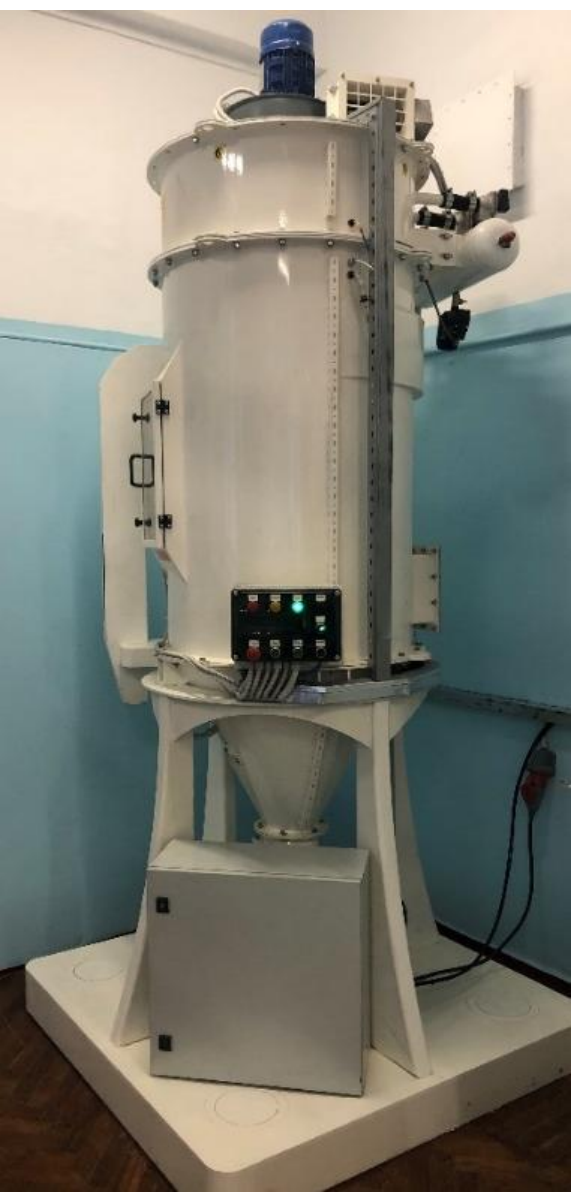

Fig. 1 - Filter type ZEO-FCS

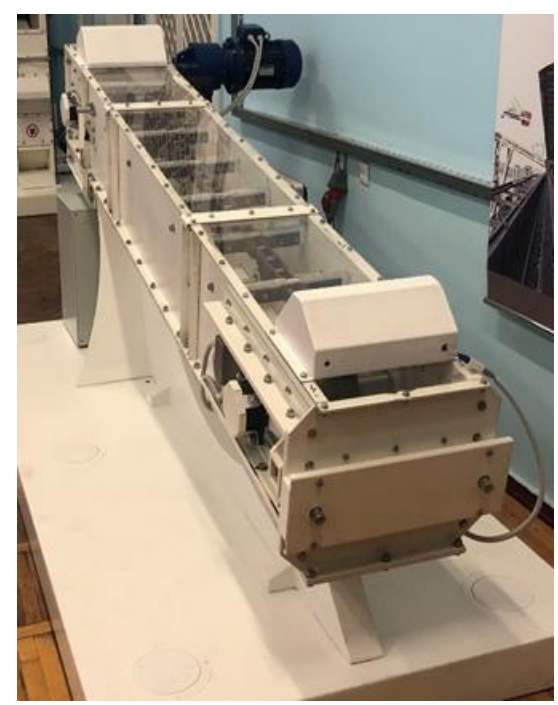

Fig. 3 - Scraper lance conveyor type ZEO-DC

transport, aspiration equipment by intelligent systems; - collection and processing of information about the work and the state of production and technological processes;

- informing the service personnel about emergency situations, the need for routine and routine repair work;

- compatibility of several similar systems in technological chains, which allows working in a single information space.

The laboratory installation SMARTINDIVIDUAL [3] presents technological and transport equipment, which is most widely used in the elevator industry.

Air filter type ZEO-FCS (Fig. 1) is designed to clean the dusty air of enterprises of the elevator, feed and flour milling industries. This filter belongs to the class of centralized aspiration. It is used for dedusting the places of grain transfer (bulk trays, discharge boxes of conveyors, unloading carts, elevator shoes, etc.) directly in the place of dust generation. To monitor and control the ZEO-FCS air filter, sensors for the analysis of dust, pressure, temperature of mechanisms, bearing assemblies, gearboxes, electric motors, vibration sensors, current and voltage control are installed.

Bucket elevator type ZEO-BE (Fig. 2) is designed to transport bulk grain products vertically in a continuous pulsating flow using a large number of buckets, which are fixed at regular intervals on an endless belt. The bucket belt passes through drums in the bottom and top of the elevator. The upper drum is driven, and the lower one is tensioning. The belt is a means of moving the buckets with the product, closed by a sealed box. Most of the ascending and descending parts of the tape pass through the pipe. The box is installed on the elevator shoe, in the upper part of it the elevator head with a drive is mounted. To monitor and control the bucket elevator, sensors are installed to control the belt speed, backwater, belt slippage, temperature of bearing assemblies, gearbox, electric motor, vibration sensors, current and voltage control.

Scraper chain conveyor type ZEO-DC (Fig. 3) is designed for transporting bulk products using a pulling device - a chain with scrapers. The bulk product is loaded into the conveyor through the loading section. A chain circulating in the box transports the product towards the drive station where the outlet is located. The operation of the scraper conveyor is monitored using sensors for speed control, open circuit, backwater. In addition, monitoring of the temperature of the bearing assemblies, gearbox, electric motor, vibration, current and voltage is provided. At the same time, the current and voltage monitoring system includes sensors in three phases, controlling the correct connection of the equipment, monitors the quality of electricity in the network.

The SMART-INDIVIDUAL system is equipped with a module with a regulation for monitoring parameters, equipment according to the passport characteristics. At the same time, the system maintains an archive and controls the timing of maintenance.

\section{Conclusions}

The SMART-INDIVIDUAL system has undeniable advantages over existing centralized control and management systems: 
- energy saving;

- intellectual assistant;

- self-diagnostics of the system.
On the basis of the software and hardware complex SMART-INDIVIDUAL at the Department of Technological Equipment for Grain Production, students are trained in the new specialty "IT-service of equipment".

\title{
REFERENCES
}

1. Morrison M. Why SMART Objectives don't work : / Mike Morrison // RapidBI. - 2011.

2. Morrison M. History of SMART Objectives : Introduction to SMART objectives and SMART Goals : / Mike Morrison // RapidBI. - 2010.

3. Ways of creating a hardware complex for managing technological and transport equipment / O.I. Гапонюк, О.В. Aleksashin // Zb. thesis add. 80-th sciences. conf. off Acad., Odessa, May 7-8. 2020 / Odessa. nat. acad. food. technologies; under the general ed. B.V. Egorov. - Odessa: ONAFT, 2020. - P. 446-447.

O.I. Гапонюк, д-р техн. наук, професор, E.mail: oleg_odessa@me.com O.В. Алексашин, канд. техн. наук, доцент, E.mail: ganna.goncharuk22@ gmail.com Г.А. Гончарук, канд. техн. наук, доцент, E.mail: aleksashin48@ gmail.com Одеська національна академія харових технологій, 112, Канатна, Одеса, Україна, 65039

\section{УПРАВЛІННЯ ТРАНСПОРТНО-ТЕХНОЛОГІЧНИМ УСТАТКУВАННЯМ ГАЛУЗІ НА БАЗІ СИСТЕМИ SMАRТ}

\begin{abstract}
Анотація
Висока продуктивність і потужність технологічних і транспортних механізмів, велика місткість $і$ кількість ємнісного обладнання, різноманітність видів зернових культур, одночасно оброблюваних на елеваторі, вимагає від оператора блискавичного прийняття рішення, оптимального вибору маршрутів транспортування зерна.

Одні з перших систем управління представляли собою величезні енергоємні шафи, з пусковою апаратурою, що дозволяють дистанційно керувати обладнанням, без функиій елементарного контролю їх роботи.

У міру збільшення обсягів зберігання, иі системи були доповнені релейними шафами, завданням яких було вести зблоковані управління кількість яких невпинно зростає механізмів, щоб хоч якось можна було керувати таким комплексом. Ці релейні шафи мали низький ступінь надійності (контактні елементи), споживали велику кількість енергії, вимагали постійна присутність непоодинокі обслуговуючого персоналу.

Прийшла епоха мікроелектроніки, яка повністю змінила уявлення про можливості систем управління. Спочатку, че здавалося дуже дорогим і не швидко окупається справою. Але з кожним роком, вартість засобів автоматизації знижується, надійність зросла до високих показників і в системи управління зерносховищ і елеваторами прийшла ия техніка.

Сучасна автоматизація на більшості українських елеваторів дозволяс управляти технологічними процесами. При иьому, багато прочесів регулюються в режимі, що вимагає досить високої кваліфікачії обслуговуючого персоналу. Обмін даних про роботу обладнання SMART-INDIVIDUAL здійснюється логічними контролерами шляхом опитування датчиків, вироблення керуючих впливів, контролю режимів роботи обладнання з відображенням в системі WEB-інтерфейсу. Система SMART-INDIVIDUAL має незаперечні переваги в порівнянні з існуючими системами иентралізованого контролю $і$ управління. Технологія SMART нерозривно пов'язана з системою диспетчерського управління та збору даних - SCADA, призначена для здійснення моніторингу та диспетчерського контролю великого числа видалених об'єктів або одного територіально розподіленого об'єкта. Система SMART-INDIVIDUAL оснащена модулем з регламентом контролю параметрів, обладнання згідно з паспортними характеристиками. При иьому, система веде архів $і$ контролює, терміни проведення технічного обслуговування. До складу лабораторної установки SMART-INDIVIDUAL представлено технологічне і транспортне устаткування, яке отримало найбільше застосування в елеваторної промисловості: фільтр повітряний типу ZEO-FCS, нория типу ZEO-BE, скребковий ланцюговий транспортер типу ZEO-DC. Ha базі програмно-апаратного комплексу SMARTINDIVIDUAL на кафедрі технологічного обладнання зернових виробництв Одеської начіональної академії харчових технологій здійснюеться навчання студентів за новою спечіальністю «IT-сервіс обладнання».
\end{abstract}

Ключові слова: SMART-INDIVIDUAL, технологія SMART, SCADA, контроль, управління, інформація, інтелектуальні системи.

\section{ЛIТЕРАТУРА}

1. Morrison M. Why SMART Objectives don't work : / Mike Morrison // RapidBI. - 2011.

2. Morrison M. History of SMART Objectives : Introduction to SMART objectives and SMART Goals : / Mike Morrison // RapidBI. - 2010.

3. Шляхи створення апаратного комплексу управління технологічним та транспортним обладнанням / O.I. Гапонюк, О.В. Алексашин // 3б. тез доп. 80-ї наук. конф. викл. акад., Одеса, 7-8 трав. 2020 р. / Одес. нац. акад. харч. технологій; під заг. ред. Б.В. Сгорова. - Одеса : ОНАХТ, 2020. - С. 446-447.

Received 10.01.2021

Reviewed 04.02.2021
Revised 27.02.2021

Approved 30.03.2021

Cite as Vancouver Citation Style

Gaponyuk O., Aleksashin O., Goncharuk G. Management of transportation and technological equipment of the industry based on the SMART system. Grain products and mixed fodder's, 2021; 21 (1, 81): 43-46. DOI https://doi.org/

Cite as State Standard of Ukraine 8302:2015

Management of transportation and technological equipment of the industry based on the SMART system. / Gaponyuk O. et al. // Grain Products and Mixed Fodder's. 2021. Vol. 21, Issue 1 (81). P. 43-46. DOI https://doi.org/ 